\section{Seasonal Water Use of Southern Highbush Blueberry Plants in a Subtropical Climate}

\author{
Jeffrey G. Williamson ${ }^{1,5}$, Luis Mejia ${ }^{1,3}$, Bradley Ferguson ${ }^{1,3}$, \\ Paul Miller ${ }^{1,4}$, and Dorota Z. Haman ${ }^{2}$
}

ADDITIONAL INDEX WORDs. Vaccinium corymbosum, V. darrowi, evapotranspiration, irrigation, lysimeter

Summary. Nonweighing drainage lysimeters were used to measure seasonal water use of mature 'Emerald' southern highbush blueberry (SHB; Vaccinium corymbosum interspecific hybrid) plants grown in pine bark beds and in pine bark amended soil in north central Florida. In the absence of rain, irrigation was applied daily with microsprinklers at $\approx 120 \%$ to $175 \%$ of reference evapotranspiration as either single or split applications. Leachate was collected and its volume determined from each lysimeter at 6- to 10-day intervals throughout the study. Water use, expressed as $\mathrm{L} /$ plant, was calculated as the difference between the amount of irrigation/rain added to lysimeters and the amount of leachate collected from lysimeters during each measurement period. Average daily water use was calculated for monthly intervals beginning in Apr. 2010 and ending in Sept. 2012. Water use increased rapidly during spring through the final stages of fruit ripening and harvest (May) with peak water use occurring during mid to late summer (July, August, and September). Plants grown in pine bark beds used more water than plants in pine bark amended soil during Apr., May, and Dec. 2010, Feb. 2011, and Mar. 2012, but there were no differences during the periods of highest water use. No differences in water use were observed between single or split-application irrigation treatments. Monthly averages for daily water use during the 30 -month period ranged from $\approx 1.75 \mathrm{~L} /$ plant in January to $\approx 8.0 \mathrm{~L} /$ plant in mid to late summer. Mean monthly crop coefficient values during the 30 -month period ranged from 0.44 in February to 0.86 in September. Canopy volume, yield, and mean berry weight were unaffected by soil or irrigation treatments.

S outhern highbush blueberry production is expanding rapidly in the low-chill regions of the southeastern United States (U.S. Department of Agriculture, 2013). Specific soil conditions are needed for optimum growth, plant health, and productivity of SHB (Williamson et al., 2006). Well-drained, porous soils that are acidic and have a minimum soil organic matter content of $2 \%$ to $3 \%$ are considered desirable (Williamson et al., 2006, 2012). Most soils in the southeastern United States where $\mathrm{SHB}$ are extensively grown do not meet these criteria and must be modified for commercial production. Pine bark is often added

\footnotetext{
The authors gratefully acknowledge The Southwest Florida Water Management District, the Florida Blueberry Growers' Association, and the National Institute of Food and Agriculture for funding this research.

${ }^{1}$ Horticultural Sciences Department, University of Florida, Gainesville, FL 32611

${ }^{2}$ Agricultural and Biological Engineering, University of Florida, Gainesville, FL 32611

${ }^{3}$ Former graduate student

${ }^{4}$ Former biologist

${ }^{5}$ Corresponding author. E-mail: jgrw@ufl.edu.
}

to rows before planting to increase substrate organic matter content and porosity, and lower $\mathrm{pH}$ (Duryea et al., 1999; Krewer and Ruter, 2012; Williamson et al., 2012). Pine bark may be added on top of the existing soil to create beds, or it may be incorporated into the soil before planting (Williamson and Crane, 2010). Pine bark beds and pine bark amended soils promote rapid establishment and growth of SHB. However, SHB grown in these soil management systems tend to be shallow rooted (Mejia, 2011; Williamson and Crane, 2010). Moreover, the soils are often sands and have less available soil moisture at field capacity than fine-textured soils. These factors add to the challenge of proper irrigation management of SHB in the southeastern United States and where these soil conditions occur (Williamson and Crane, 2010).

Regional recommendations for blueberry (Vaccinium) irrigation exist, but few studies report actual water use or crop evapotranspiration (ETc) for blueberry, especially in the southeastern United States where SHB on heavily amended soils predominate. Dourte et al. (2010) studied plant water use of 'Star' SHB for a 12 month period in north central Florida. They reported crop coefficient $(K c)$ values ranging from 0.59 to 1.10 and maximum ETc values of $\approx 6 \mathrm{~mm} \cdot \mathrm{d}^{-1}$. Most studies of blueberry irrigation and water requirements have been conducted with northern highbush blueberry ( $V$. corybosum), where climatic conditions and cultural practices differ greatly from those where SHB are grown. Bryla and Strik (2007) reported a peak ETc of $\approx 10 \mathrm{~mm} \cdot \mathrm{d}^{-1}$ for 'Duke' northern highbush blueberry in Oregon. In New Jersey, up to $4.5 \mathrm{~L}$ of water were used per d for 6-year-old highbush blueberry (Storlie and Eck, 1996). The objective of this study was to determine seasonal water use of mature, well-irrigated, SHB grown under two soil treatments (pine bark beds and pine bark amended soil) and two irrigation schedules (once per day and twice per day).

\section{Materials and methods}

The experiment was located in a 0.8 -acre blueberry planting at the University of Florida Plant Science Research and Education Unit (lat. $29^{\circ} 24^{\prime} 300^{\prime \prime} \mathrm{N}$, long. $82^{\circ} 8^{\prime} 521^{\prime \prime} \mathrm{W}$ ) near Citra, FL. The soil is classified as Arredondo sand (loamy, siliceous, semiactive, hyperthermic Grossarenic Paleudults), $0 \%$ to $5 \%$ slope, with sandy Ap, E1, E2, and EB horizons. The blueberry planting was established in

\begin{tabular}{llll}
\hline $\begin{array}{l}\text { Units } \\
\text { To convert U.S. to SI, } \\
\text { multiply by }\end{array}$ & U.S. unit & SI unit & $\begin{array}{l}\text { To convert SI to U.S., } \\
\text { multiply by }\end{array}$ \\
\hline 0.4047 & acre(s) & $\mathrm{ha}$ & 2.4711 \\
0.3048 & $\mathrm{ft}$ & $\mathrm{m}$ & 3.2808 \\
3.7854 & gal & $\mathrm{L}$ & 0.2642 \\
0.7457 & horsepower & $\mathrm{kW}$ & 1.3410 \\
2.54 & inch(es) & $\mathrm{cm}$ & 0.3937 \\
25.4 & inch(es) & $\mathrm{mm}$ & 0.0394 \\
0.4536 & lb & $\mathrm{kg}$ & 2.2046 \\
28.3495 & $\mathrm{oz}$ & $\mathrm{g}$ & 0.0353 \\
0.7646 & yard & $\mathrm{m}^{3}$ & 1.3080
\end{tabular}


Winter 2006-07 and consisted of 'Emerald', 'Jewel', 'Windsor', 'Star', 'Springhigh', and 'Sweetcrisp' SHB plants. Plant spacing was $3 \mathrm{ft}$ in-row with $10 \mathrm{ft}$ between-rows (1452 plants/ acre). The experiment was conducted in four adjacent rows containing 'Emerald' and 'Jewel' plants using only the 'Emerald' plants. The inrow plant sequence alternated between three consecutive plants of each cultivar.

Twelve nonweighing, drainage lysimeters were installed during Nov. 2009 through Dec. 2009. In each case, the center 'Emerald' plant in a three-plant plot was removed and a lysimeter was installed in its place. The soil horizons were removed separately at each installation site. Each lysimeter was centered in the row middle and leveled. Soil was added around outside the lysimeter walls to stabilize its position. Afterward, soil was added to the inside of the lysimeter by horizon and tamped and irrigated several times during refilling. After installation, each lysimeter was irrigated with 3 to 4 inches of water to settle the soil and test the lysimeter drainage. One to two days after irrigating, one 3-year-old 'Emerald' plant from the same field and with the corresponding soil treatment was transplanted to the top of each lysimeter. Transplanting large plants was accomplished during dormancy (Dec. 2009) by inserting a plywood board under the bed and transporting the plant on the plywood support to the lysimeter. The root system remained intact during transplanting and conformed to the surface dimensions of the lysimeter. The walls of the lysimeters extended $\approx 0.5$ to 0.75 inches above the soil surface at the row middles.

The lysimeter dimensions were 36 inches in-row by 48 inches across row by 26 inches deep (volume $=150$ gal). Lysimeters were constructed using 3/4-inch-thick marine-grade, pressuretreated, plywood. The lysimeter walls were vertical on the ends and vertical for the top 14 inches on the sides. The remaining 12 inches were angled in at $22^{\circ}$ to form a V-shaped bottom. An oil-based sealant was used on all seams and joints to prevent leakage. Free water from the lysimeter drained into a 10-inch-diameter PVC pipe below the lysimeter that was capped on both ends and used as a collection tank.
Each collection tank was angled at $10^{\circ}$ and water was withdrawn from the lower end through a port at about weekly intervals with a $1 / 4$ horsepower electric vacuum pump (Dayton 32409B; Grainger, Lake Forest, IL) and the volumes were measured. Soil moisture content was monitored in representative lysimeters with time domain reflectometry (TDR) sensors (S616-L; Campbell Scientific, Logan, UT) placed horizontally at 6-, 14-, and 22-inch depths and data were collected with a data logger (CRl000; Campbell Scientific).

The soil management treatments were 1) 6 inches of pine bark placed on top of the native soil with planting done in the pine bark layer and 2) a $50 \%$ pine bark (vol.): $50 \%$ soil (vol.) mixture $\approx 6$ inches deep created by mixing a 3 -inch layer of pine bark into the top 3 to 4 inches of soil. Planting was done in the bark/soil mixture. The two irrigation schedules were l) irrigation applied once per day (predawn) in the absence of rain and 2) irrigation applied twice per day (predawn + midafternoon) in the absence of rain. Total irrigation volume applied to the lysimeter plants was the same for both irrigation schedules and was calculated from emitter outputs and irrigation run times. Irrigation was applied daily in the absence of rain. Irrigation rates were adjusted twice during spring and once each during summer, fall, and winter of each year to provide a range of $120 \%$ to $175 \%$ reference evapotranspiration (ETo) to ensure that plant growth or water use was not reduced by deficit irrigation during the study. Irrigation was applied using $5.6 \mathrm{gal} / \mathrm{h}$ microsprinkler emitters (MAB18Bl; Maxijet, Dundee, FL) with an $180^{\circ}$ downward deflected spray pattern and a 2 - $\mathrm{ft}$ spray radius. Two nozzles were positioned in each lysimeter so that there was a minimum of $80 \%$ soil surface coverage in the lysimeter without overspray. A rain shutoff device (Mini-Clik; Hunter Industries, San Marcos, CA) prevented irrigation when rainfall of 0.25 inch or greater occurred. An event counter tracked the number of irrigation events for all treatments. Overhead irrigation consisting of 3/4-inch impact sprinklers with $5 / 32$-inch nozzles (30EP; Rainbird, Azusa, CA) was used during plant establishment (Jan. to Mar. 2010) and for freeze protection (January to March each year).
All meteorological data except rainfall and overhead irrigation were taken from a weather station (Florida Automated Weather Network, 2013) located at the research center (lat. $29^{\circ} 24^{\prime} 37^{\prime \prime} \mathrm{N}$, long. $82^{\circ} 10^{\prime} 23^{\prime \prime} \mathrm{W}$ ). Rainfall and overhead irrigation for freeze protection were measured with a rain gauge (RG202M; Rainman Weather, Jacksonville, FL) located in the planting.

ETc was calculated for each collection period according to the water balance equation described by Boman (1994): ETc $=[\mathrm{IR}+\mathrm{k}(\mathrm{PR})-\mathrm{DR}] /$ $\mathrm{ND}$, where $\mathrm{ETc}=$ average daily ETc, $\mathrm{IR}=$ irrigation volume applied, $\mathrm{PR}=$ precipitation depth, $\mathrm{k}=$ constant to convert rainfall depth to volume, $\mathrm{DR}=$ measured drainage from the lysimeter, and ND = number of days.

Drainage water was collected from each lysimeter at 6- to $10-\mathrm{d}$ intervals beginning in Apr. 2010, and continuing until Sept. 2012. Monthly estimates of ETc were calculated from the individual collection intervals. When more than 4 inches of rainfall or overhead irrigation occurred during an individual collection period and data were affected by surface runoff or lysimeter flooding, those data were excluded from the monthly calculations of plant water use. This occurred from overhead irrigation for freeze protection in Jan. 2011, Feb. 2011, Jan. 2012, and Feb. 2012; and from rain events in June 2010, Aug. 2011, Oct. 2011, June 2012, and Aug. 2012. Irrigation system repair and maintenance prevented data collection during a 2 -week period in Dec. 2011 and a l-week period in Jan. 2012. Water use data from one lysimeter (bark bed irrigated once per day) was excluded beginning Jan. 2011 due to highly variable ETc values observed during 2011 and 2012. Monthly averages of daily ETc along with ETo from the weather station for the same periods were used to estimate monthly $K \mathrm{c}$ values where $K \mathrm{c}=\mathrm{ETc} / \mathrm{ETo}$ and ETo was calculated using the modified Penman equation descried by Haman et al. (1997).

Berry yield per plant was determined for 2010,2011, and 2012, by harvesting and weighing all ripe berries at 3- to 4-d intervals beginning in early April and continuing until late May or early June of each year. Mean berry weight was determined for each harvest date by weighing 25-berry 
subsamples. Plant canopy volumes were determined in June of each year before summer pruning by measuring plant height and width in two directions (parallel and perpendicular to the row) and assuming a cylindrical canopy shape. Summer pruning (June), fertilization, and pest and disease management were done in accordance with standard commercial practices for Florida (Williamson and Crane, 2010; Williamson et al., 2006, 2013).

A randomized complete block design with a factorial arrangement of treatments (two soil management systems $\times$ two irrigation frequencies) was used. There were 12 lysimeter plants. Each treatment was replicated three times with single-plant plots (one plant per lysimeter). Two additional nonlysimeter plants per treatment were used in combination with the lysimeter plants giving five replications per treatment for yield and canopy volume determinations. Data were analyzed by PROC ANOVA using SAS (version 9.2; SAS Institute, Cary, NC).

\section{Results and discussion}

Plant growth AND yield. Canopy volume, berry weight, and yield treatments, and there were no consistent soil by irrigation treatment interactions for these response variables. Their yearly averages across soil and irrigation treatments are presented in Table 1. Although canopy height in 2010 was greater for plants grown in pine bark than for plants grown in bark incorporated soil (data not shown), this did not result in a difference in canopy volume. All treatments produced commercially viable yields (usually over $10 \mathrm{lb} /$ plant) during each of the three seasons. Plants were healthy and vigorous with only one of the 12 lysimeter plants (bark incorporated soil receiving one irrigation per day) showing signs of declining were unaffected by soil or irrigation

health from stem blight [ Botryosphaeria dotbidea, Lasiodiplodia theobromae, and Neofusicoccum ribis (Milholland, 1972)] during the last year of the study. Data from this plant were excluded for 2012.

Plant water use. No consistent soil by irrigation treatment interactions were found for plant water use. Generally, seasonal plant water use patterns were similar regardless of soil management treatments (Fig. 1A). However, plants grown on bark beds used significantly more water than plants grown in bark incorporated soil during Apr. 2010, May 2010, Dec. 2010, Feb. 2011, and Mar. 2012. Higher water use during Apr. 2010 and May 2010 coincided with greater plant height (measured in June) for plants on bark beds compared with plants grown on bark incorporated soil. Since plant growth was unaffected in subsequent years, this effect in 2010 may have been due to quicker plant establishment and more initial growth during the spring following transplanting for the pine bark bed plants compared with the bark incorporated plants. However, in both 2011 and 2012, greater plant water use was observed early in the annual growth cycle (Feb. 2011 and Mar. 2012) for plants grown in pine bark beds compared with plants grown in pine bark incorporated soil, but not later during the growing season of each year (Fig. 1A). Water use was also greater for the bark beds during Dec. 2010 (onset of dormancy). The reason(s) for these temporary differences in early and late season water use are not readily apparent. Apart from these temporary differences, plant water use was similar between the two soil management systems throughout the study.

Plant water use was greater for the twice per day treatment than for the once per day treatment for July 2011 (Fig. 1B). For all other

Table 1. Canopy volume and fruit production of 'Emerald' blueberry in 2010-12.

\begin{tabular}{lccc}
\hline Yr & Canopy vol $\left(\text { yard }^{3}\right)^{\mathrm{y}}$ & Mean berry wt $(\mathrm{g})^{\mathrm{y}}$ & ${\text { Yield }(\mathrm{lb} / \text { plant })^{\mathrm{y}}}^{\mathrm{y}}$ \\
\hline 2010 & 2.17 & 1.88 & 14.5 \\
2011 & 3.41 & 2.11 & 15.8 \\
2012 & 3.46 & 1.57 & 10.2 \\
\hline
\end{tabular}

${ }^{\mathrm{z}}$ Canopy volume, berry weight, and yield were not significantly affected by irrigation frequency (once or twice per day), soil treatment (bark bed or incorporated bark), or the interaction between the two in $2010-12(P<0.05)$.

${ }^{y} 1$ yard $^{3}=0.7646 \mathrm{~m}^{3}, 1 \mathrm{~g}=0.0353 \mathrm{oz}, 1 \mathrm{lb}=0.4536 \mathrm{~kg}$. measuring dates, plant water use did not differ between the two irrigation treatments. However, there was a nonsignificant trend $(0.05<P \leq 0.10)$ for greater water use of plants that were irrigated twice per day for Sept. 2011 and May 2012. This tendency for greater water use by plants irrigated twice per day may have resulted from greater evaporation of irrigation water since half the irrigation water for the split-application treatment was applied during midafternoon compared with only predawn applications for the once per day irrigation schedule.

Mean monthly values for daily water use were averaged across treatments and years to provide an overall seasonal pattern of plant water use (Fig. 2A). Plant water use was low during January and February, but increased rapidly in March during postbloom, foliation, and fruit development. Average daily plant water use continued to increase rapidly from April through May during the later stages of fruit development and harvest. Summer pruning (June) removed $\approx 30 \%$ to $40 \%$ of the existing plant canopy and resulted in a temporary decline in plant water use. Plant water use increased from July through September as plant canopies regrew following summer pruning. In general, the period of greatest water demand was from May through September. Plant water use declined rapidly during October, November, and December.

Our peak water use is in general agreement with previous studies. Dourte et al. (2010) reported peak water use of 'Star' SHB in north central Florida to occur in July at $\approx 6$ $\mathrm{mm} \cdot \mathrm{d}^{-1}$. They also reported a temporary decline in water use in June following summer pruning. In New Jersey, up to $4.5 \mathrm{~L}$ of water were used per d for 6-year-old highbush blueberry (Storlie and Eck, 1996). Their plants had smaller canopy volumes $\left(\approx 0.6 \mathrm{~m}^{3}\right)$ and lower yields than the plants in our study. The differences in canopy size and fruit yield at least partially account for lower plant water use reported in their study compared with ours. Bryla and Strik (2007) found that peak water use was cultivar dependent with 'Duke' having greater water use $\left(\approx 10 \mathrm{~mm} \cdot \mathrm{d}^{-1}\right)$ than 'Bluecrop' $\left(\approx 7 \mathrm{~mm} \cdot \mathrm{d}^{-1}\right)$ or 'Elliott' $\left(\approx 5 \mathrm{~mm} \cdot \mathrm{d}^{-1}\right)$. When our plant water use data were expressed as depth 


\section{Research Reports}
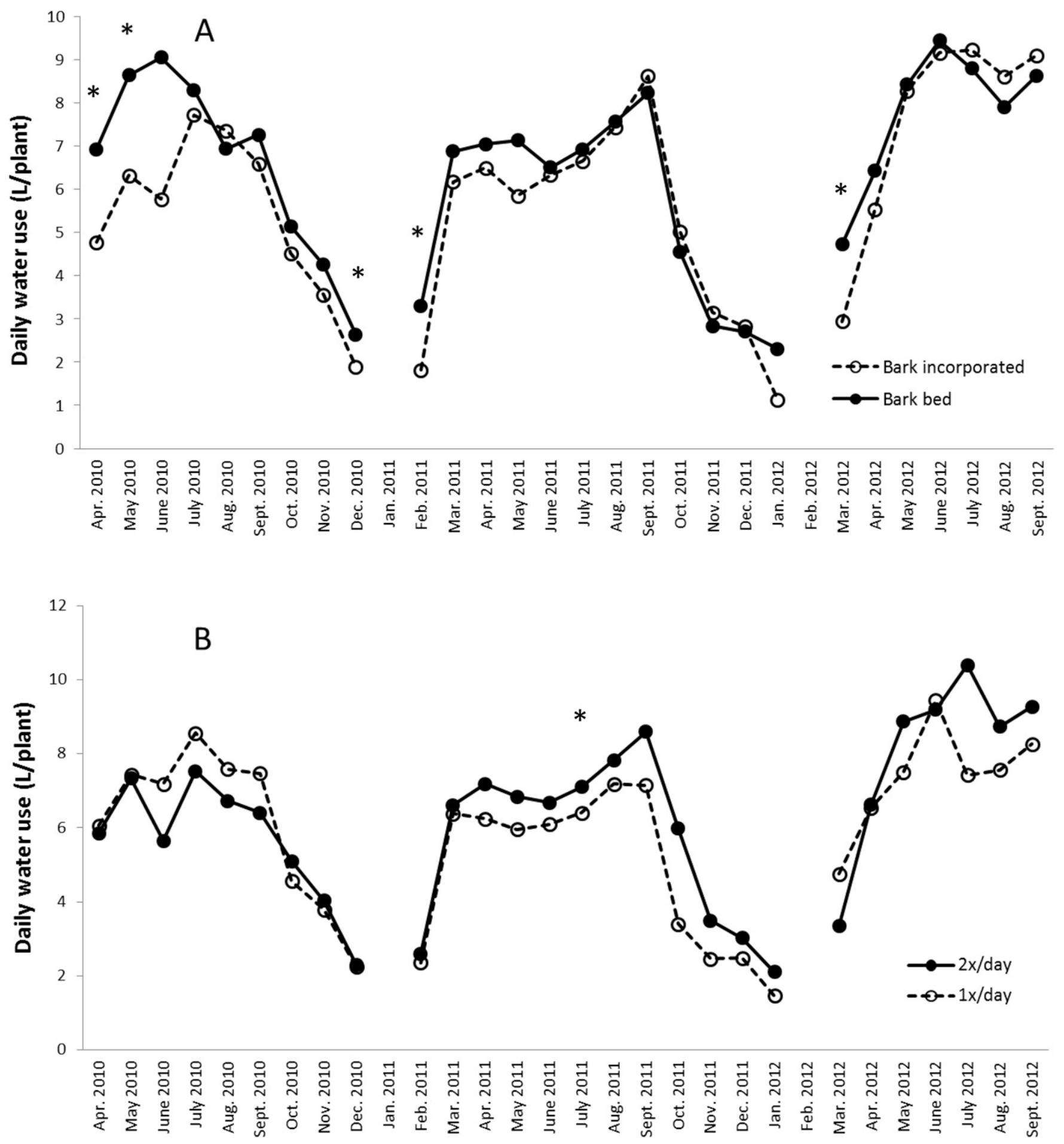

Fig. 1. Monthly averages of daily water use of mature 'Emerald' southern highbush blueberry from Apr. 2010 to Sept. 2012 in pine bark beds and in pine bark incorporated soil (A), and irrigated once or twice per day $(\mathrm{B}) .{ }^{*} \mathrm{Means}$ differ at $P \leq 0.05 ; 1 \mathrm{~L}=$ 0.2642 gal.

rather than volume, peak water use for 'Emerald' $\mathrm{SHB}$ was $\approx 7 \mathrm{~mm} \cdot \mathrm{d}^{-1}$ from the lysimeter area, which comprised the bed, but did not include the row middles (data not shown). Other estimates of blueberry water requirements from various production regions and for different blueberry species vary widely. Eck (1988) suggested that blueberry plants generally require a constant supply of moisture during the growing season equivalent to 1.0 to 1.5 inches per week. In the northeastern United States, Ross et al. (1985) suggested that $5 \mathrm{~L} /$ plant per day were needed for 3- and 4-year-old highbush blueberry plants. Conversely, 6 to $8 \mathrm{gal} /$ plant per day (22.7 to $30.3 \mathrm{~L} /$ plant per day) was recommended for rabbiteye blueberry ( $V$. virgatum) during periods of peak water demand in the southeastern United States (Himelrick and Curtis, 1999; Purs, 1999). Plant 

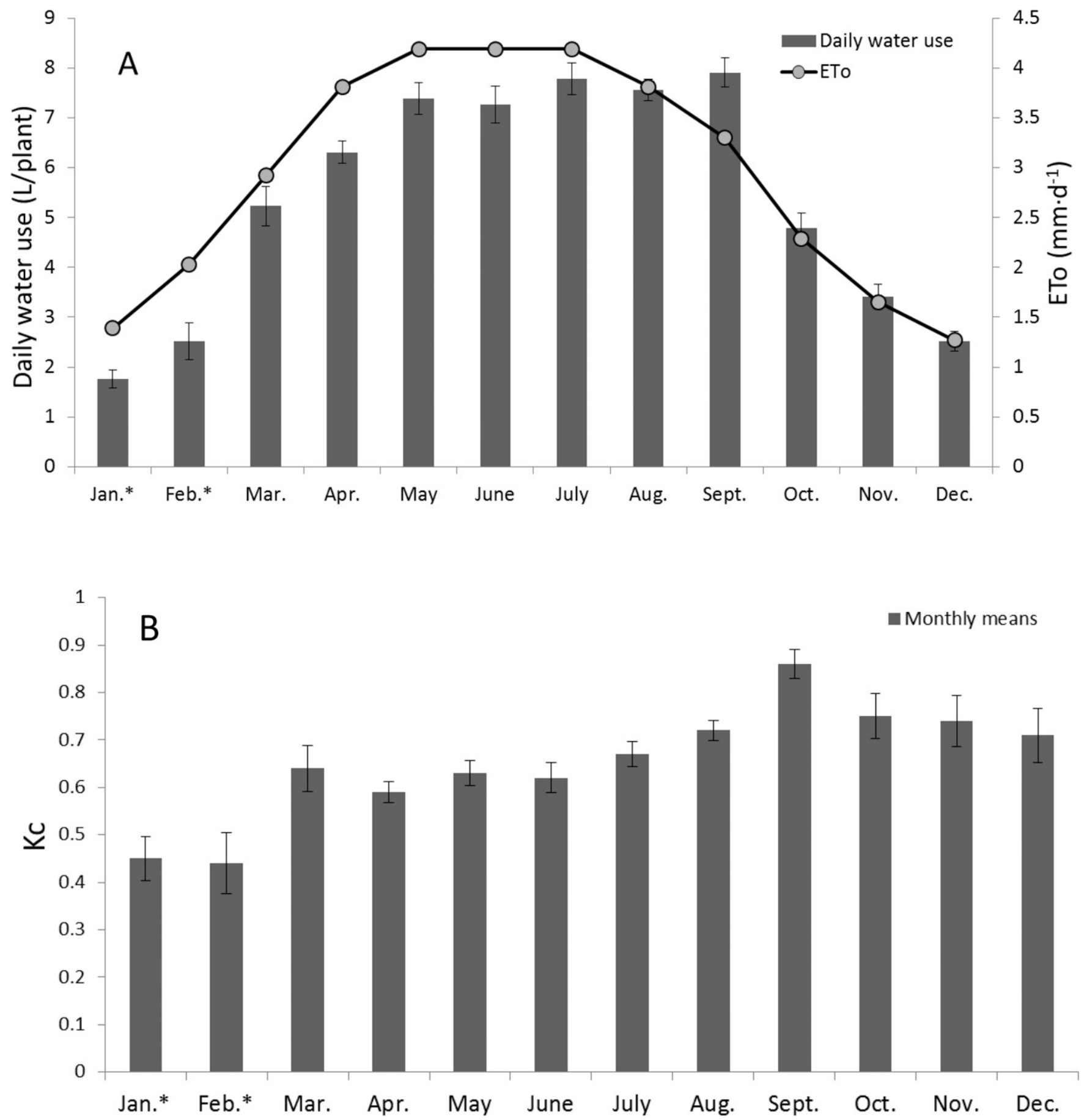

Fig. 2. Monthly means $( \pm \mathrm{SE})$ of daily water use of mature 'Emerald' southern highbush blueberry plants averaged across treatments and years, and monthly reference evapotranspiration (ETo) averaged across years from Apr. 2010 to Sept. 2012 (A), and monthly crop coefficients $(K \mathrm{c})$ for mature 'Emerald' southern highbush blueberry plants averaged across treatments and years from Apr. 2010 through Sept. 2012 (B). Kc values are based on a 3 - $\mathrm{ft}(0.9 \mathrm{~m})$ in-row by 10 - $\mathrm{ft}(3.0 \mathrm{~m})$ between-row plant spacing and 1452 plants/acre (3588.0 plants/ha). * Mean for 1 year due to complications from overhead irrigation for freeze protection; $1 \mathrm{~L}=0.2642 \mathrm{gal}, 1 \mathrm{~mm}=0.0394$ inch .

species, canopy size, gross canopy morphology, cultural practices, planting density, as well as environmental conditions potentially influence plant water use and may account for the wide range of plant water requirements reported for blueberry. For example, per plant water use in this study would be expected to be much lower than for rabbiteye blueberry plants that are typically larger than SHB plants.

Crop coefficients. Monthly averages of daily water use averaged across treatments and years were used to estimate monthly Kc's for an annual growth cycle (Fig. 2B). Kc values were low in January and February when plants were mostly defoliated and initiating bloom. A large increase in Kc was observed in March which coincided with the initiation and development of the spring vegetative growth flush and early fruit 
development. Following summer pruning (June), Kc steadily increased during mid to late summer, concomitant with canopy regrowth following pruning, seasonally high temperatures, and long daylengths. The highest $K \mathrm{c}$ (0.86) was observed in September when full canopy regrowth had occurred. Allen et al. (1998) noted that $K c$ values for deciduous orchard crops can vary depending in part on plant spacing and canopy coverage. Our 10 - $\mathrm{ft}$ row spacing resulted in $\approx 50 \%$ to $60 \%$ canopy coverage, which may account for a lower maximum $K c$ value (0.86) compared with Allen et al. (1998) who reported a basal midseason $K c$ of 1.00 for bush crops in a subhumid climate. Although plant water use dropped dramatically during fall (October through December), Kc values remained relatively high. Under Florida conditions, SHB leaves remain photosynthetically active during fall and early winter (R.L. Darnell, personal communication). 'Emerald' SHB has strong evergreen tendencies and complete defoliation of 'Emerald' lysimeter plants did not occur until January as a result of hydrogen cyanamide applications in late December and subfreezing temperatures in December and January. Kc values for the lysimeter plants probably remained relatively high during fall and early winter because their leaves remained photosynthetically active during that period. Bryla (2011) reported a $K c$ of $\approx 0.85$ during the latter part of the season for northern highbush blueberry before the onset of dormancy. The acquisition of dormancy and defoliation in subtropical climates is highly dependent on cultivar, weather conditions during any given year, and cultural practices such as irrigation, fertilization, and application of hydrogen cyanamide. In this study, complete defoliation of 'Emerald' plants did not occur until January (after the application of hydrogen cyanamide). Therefore, mean monthly $K c$ values declined in January and reached their lowest point in February when plants were mostly defoliated and in early stages of flowering.

\section{Conclusion}

Seasonal ETc of well-irrigated, mature, 'Emerald' SHB was determined for a 30-month period. Seasonal plant water use patterns were similar across soil and irrigation treatments and years. Water use increased rapidly beginning in late winter and spring and continued to increase through the fruit development period. Water use and $K c$ values steadily increased following summer pruning through the remainder of the summer concomitant with canopy regrowth. Although plant water use declined rapidly during the fall and early winter, $K \mathrm{C}$ values remained relatively high until late winter (after defoliation). Fall and winter $K c$ values of SHB in subtropical climates are subject to influence by many factors that potentially influence defoliation including weather, leaf disease pressure, and cultural practices such as irrigation, fertilization, and hydrogen cyanamide use. Furthermore, in some subtropical climates with very lowchill accumulation, SHB blueberries are grown under an "evergreen" or "nondormant" system without winter defoliation. Under these conditions, winter and early spring $K \mathrm{c}$ values would probably be higher than reported in this study. The information presented here provides baseline data for future experiments to evaluate the efficacy and water use efficiency of ET-based irrigation programs for SHB blueberry in subtropical climates. Furthermore, plants grown in pine bark amended soil (using half the amount of pine bark as beds) did not differ in canopy volume, berry yield, or mean berry weight compared with plants grown on pine bark beds. Additionally, no effects of irrigation frequency (once per day vs. twice per day) were found for canopy volume, berry yield, or mean berry weight for microsprinklerirrigated SHB.

\section{Literature cited}

Allen, R.G., L.S. Pereira, D. Raes, and M. Smith. 1998. Crop evapotranspiration - guidelines for computing crop water requirements. FAO Irr. Drainage Paper 56. Food Agr. Organization United Nations, Rome, Italy.

Boman, B. 1994. Evapotranspiration by young Florida flatwoods citrus trees. J. Irr. Drain. Eng. 120:80-87.

Bryla, D.R. 2011. Crop evapotranspiration and irrigation scheduling in blueberry, evapotranspiration. In: G. Gerosa (ed.). From measurements to agricultural and environmental applications. 20 June 2013. <http://www.intechopen.com/books/ evapotranspiration-frommeasurements-toagricultural-and-environmental-applications/ crop-evapotranspiration-and-irrigationschedulingin-blueberry>.

Bryla, D.R. and B.C. Strik. 2007. Effects of cultivar and plant spacing on the seasonal water requirements of highbush blueberry. J. Amer. Soc. Hort. Sci. 132:270-277.

Dourte, D.R., D.Z. Haman, and J.G. Williamson. 2010. Crop water requirements of mature southern highbush blueberries. Intl. J. Fruit Sci. 10:235-248.

Duryea, M.L., R.J. English, and L.A. Hermansen. 1999. A comparison of landscape mulches: Chemical, allelopathic, and decomposition properties. J. Arboricult. 25:88-97.

Eck, P. 1988. Blueberry science. Rutgers Univ. Press, New Brunswick, NJ.

Haman, D.Z., R.T. Pritchard, A.G. Smajstrla, F.S. Zazueta, and P.M. Lyrene. 1997. Evapotranspiration and crop coefficients for young blueberry in Florida. Appl. Eng. Agr. 13:209-216.

Himelrick, D. and L.M. Curtis. 1999. Alabama Ag. Irrigation Info. Network: Commercial blueberries. Alabama Coop. Ext. Serv. ARN-663.

Florida Automated Weather Network. 2013. Report generator. I Sept. 2013. $<$ http://fawn.ifas.ufl.edu/data/reports/>.

Krewer, G. and J. Ruter. 2012. Fertilizing highbush blueberries in pine bark beds. 1 July 2013. <http://extension.uga.edu/ publications/files/pdf/B\%201291_3. PDF $>$.

Mejia, L.E. 2011. Growth, yield and stem water potential of southern highbush blueberries (Vaccinium corymbosum interspecific hybrid) in pine bark amended soils. Univ. Florida, Gainesville, MS Thesis.

Milholland, R.D. 1972. Histopathology and pathogenicity of Botryosphaeria dothidea on blueberry stems. Phytopathology 62:654-660.

Purs, E.E., Jr. 1999. Commercial blueberry production. Louisiana State Univ. Agr. Ctr., Louisiana Coop. Ext. Serv., Publ. 2363.

Ross, D.S., R.A. Parsons, and H.E. Carpenter. 1985. Trickle irrigation in the eastern United States. Northeast Reg. Agr. Eng. Serv. Publ. NRAES-4, Cornell Univ., Ithaca, NY.

Storlie, C.A. and P. Eck. 1996. Lysimterbased crop coefficients for young highbush blueberries. HortScience 31:819-822.

U.S. Department of Agriculture. 2013. Noncitrus fruits and nuts preliminary 
2012 summary. 16 June 2013. <http:// usda.mannlib.cornell.edu/usda/nass/ NoncFruiNu//2010s/2013/NoncFruiNu01-25-2013.pdf>.

Williamson, J.G. and J.H. Crane. 2010. Best management practices for temperate and tropical/subtropical fruit crops in Florida: Current practices and future challenges. HortTechnology 20:111-119.
Williamson, J.G., P.H. Harmon, O.E. Liburd, and P. Dittmar. 2013. 2013 Florida blueberry integrated pest management guide. I July 2013. <https://edis.ifas.ufl. edu/pdffiles/HS/HS38000.pdf>.

Williamson, J.G., G. Krewer, G. Pavlis, and C.M. Mainland. 2006. Blueberry soil management and irrigation, p. 6074. In: N.F. Childers and P.M. Lyrene (eds.). Blueberries: For growers, gardeners and promoters. Dr. Norman F. Childers Hort. Publ., Gainesville, FL.

Williamson, J.G., J.W. Olmstead, and P.M. Lyrene. 2012. Florida's commercial blueberry industry. 16 June 2013. $<$ https://edis.ifas.ufl.edu/pdffiles/AC/ AC03100.pdf>. 